\title{
Crystal and Molecular Structure of Platinum(II) Complex with Bis(diphenylphosphino)methane
}

\section{KARWAN OMER ALI ${ }^{*}$, HIKMAT ALI MOHAMMAD², THOMAS GERBER ${ }^{3}$ and ERIC HOSTEN ${ }^{4}$}

\author{
${ }^{1}$ College of Science, University of Halabja, Halabja, Kurdistan Regional Government, Iraq. \\ ${ }^{2}$ College of Education, Department of Chemistry, University of Salahaddin, \\ Hewler, Kurdistan Regional Government, Iraq. \\ ${ }^{3,4}$ Department of Chemistry, Nelson Mandela University, Port Elizabeth, South Africa. \\ ${ }^{*}$ Corresponding author E-mail: karwan.ali@uoh.edu.iq
}

http://dx.doi.org/10.13005/ojc/350511

(Received: July 28, 2019; Accepted: October 06, 2019)

\begin{abstract}
Platinum(II) complex consisting of the tertiarydiphosphine (dppm) ligand had been prepared from $\mathrm{PdCl}_{2}$ with one equiv of dppm ligand to form $\left[\mathrm{PtC}_{2}(\mathrm{dppmCl})\right]$ complex where as $\mathrm{dppmCl}$ is bis(diphenylphosphino) chloromethene. Crystal was grown in dichloromethane by slow evaporation process and characterized by X-ray crystallography technic. The complex structure synthesized based upon the identification using X-ray Crystallography and FTIR was $\left[\mathrm{PtC1}_{2}(\mathrm{dppmCl})\right]$, the ligand dppm coordinated to the meta centre as bidentate chelating ligand and form square planar arrangement around $\mathrm{Pt}(\mathrm{II})$ metal centre. The bond distances of Pt-P1, Pt-P2, Pt- Cl1 and Pt-Cl are 2.217 (2), 2.217 (2), 2.3661 (19) and 2.3661 $\mathrm{A}^{\circ}$ respectively. The characterized results of $\mathrm{Pt}(\mathrm{II})$ complex using $\mathrm{X}$-ray analysis illustrated that $\left[\mathrm{PtC}_{2}(\mathrm{dppmCl})\right]$ Complex form monoclinic crystal with unit cell dimensions of $a=16.2034(5), b=7.8274(2)$, and $c=19.2496(6) A^{\circ}$, with $\beta=98.918(1)^{\circ}$, $\mathrm{Z}=4$, calculated density $=1.838 \mathrm{mg} / \mathrm{m}^{3}, \mathrm{~T}=200 \mathrm{k}$ and space group $\mathrm{C}_{2} / \mathrm{c}$.
\end{abstract}

Keywords: Bis(diphenylphosphino)methane (dppm), Bis(diphenylphosphino)chloromethene (dppmCl), Crystal structure, FT-IR spectroscopy, Pt(II) complex.

\section{INTRODUCTION}

Phosphine ligands have been intensively used in coordination chemistry because of their electron releasing capacity ${ }^{1}$. The phosphine ligands can be organized based on the type of substituents bonded to the phosphorus atom ${ }^{2}$. Trivalent phosphorus compound are commonly used as mono- and bi-dentate ligands in the organometallic and coordination compounds of the transition metals ${ }^{3}$. Bisphosphanes are class of bidentate ligand that contain two phosphine atoms joined by a bridge ${ }^{4}$. The bridge, for instance, could involve only one or more methylene bridge or a few phenyl rings with heteroatoms joined ${ }^{5}$. The structure of the methylene bridge and the substituents joined

This is an Open Access article licensed under a Creative Commons license: Attribution 4.0 International (CC- BY). Published by Oriental Scientific Publishing Company @ 2018

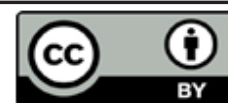


to the phosphine atoms influence the chemical reactivity of the bisphosphanes ligand in coordination complexes by means of steric and electronic effects ${ }^{6,7}$. Phosphanes ligands usually attached to the metal center through the pair of valence electrons on the phosphorus ${ }^{8}$. The 'R' group substituents bound to the phosphorus can then influence the behavior of the phosphine as a ligand bound to a metal center ${ }^{9}$. Phosphine ligands are usually strong $\sigma$-donor ligands and only weak $\pi$-acceptors ${ }^{10}$. This impact can be expanded with electron-donating groups in the rest $R$, although electron with-drawing groups in ' $R$ ' favor the $\pi$-acceptor back bonding ${ }^{11}$. In the present work, the synthesized platinum complex has chlorine atom on the methylene group of dppm ligand that cause increase in the $\pi$-acceptor back bonding of dppm ligand and increase the stability of complex.

\section{EXPERIMENTAL}

\section{Instrumentation and Materials}

The FTIR spectra of complexes were recorded on a Shimadzu IRAffinity-1S FTIR Spectrophotometer in the range $\left(4000-200 \mathrm{~cm}^{-1}\right)$ by using cesium iodide disc, and IR spectra of the compound were recorded on Shimadzu, FT-IR spectroscopy Mod IR Affinity-1CE spectrophotometer in the region (4000-400 $\left.\mathrm{cm}^{-1}\right)$ by using potassium bromide disc. Melting point of the complex were recorded by Melting Point-MPD-100 Pixel Technology CO apparatus.

The compounds platinum dichloride and bis(diphenylphosphino)methane were commercially valid and be valid from Yacoo chem. China. All solvents used in this research were commercial products and were used without further purification.

\section{Synthesis of $\left[\mathrm{PtCL}_{2}(\mathrm{dppmCl})\right]$ complex}

Bis(diphenylphosphino)methane $(0.7687 \mathrm{~g}$, $2 \mathrm{mmol})$ was dissolved in $\left(20 \mathrm{~cm}^{3}\right)$ dichloromethane and treated with a $\left(20 \mathrm{~cm}^{3}\right)$ solution of platinum dichloride $(0.5319 \mathrm{~g}, 3 \mathrm{mmol})$ in a mixture of ethanol and concentrate hydrochloric acid in the same portion. The reaction mixture was stirred at $40^{\circ} \mathrm{C}$ for $3 \mathrm{~h}$ and allowed to evaporate slowly at $25^{\circ} \mathrm{C}$. The yellow precipitate was formed. The yellow crystal was formed by slow evaporation of a dichloromethane solution of the complex after one week, Yield: $1.300 \mathrm{~g}(87 \%), \mathrm{m}$. p.: $\left(310^{\circ} \mathrm{C}\right)$. M.Wt: $650.378 \mathrm{~g} / \mathrm{mol}$.

\section{RESULTS AND DISCUSSION}

X-ray data of $\left[\mathrm{Pt}\left(\mathrm{k}^{2}-\mathrm{dppmCl}\right) \mathrm{Cl}_{2}\right]$ complex were collected at $200 \mathrm{~K}$ in the Mo $\mathrm{K} \alpha$ radiation (0.71073 A) on a Bruker Kappa Apex II diffractometer with graphite monochromated $(\lambda=0.71073 \AA)$. The program APEX-Trak was utilized to data accumulation and SAINT for cell refinement and data reduction ${ }^{12}$. The structure was carry out by straight manners applying SIR $97^{13}$ and refined by smallest-squares procedures utilizing SHELXL-97 ${ }^{14}$. The needle yellow crystals were obtained by slow evaporation of dichloromethane solution of the complex at room temperature after seven days, these crystals were sent to X-ray analysis. Fig. 1 show the molecular geometry of the complex. The complex is composed of closely packed monoclinic molecule of [Pt(k2-dppmCl) $\left.\mathrm{Cl}_{2}\right]$. In the complex the $\mathrm{Pt}$ atom is surrounded to form square planer by two phosphorus atoms and two chlorine atoms. The bis(diphenylphosphino)methane contain two $\mathrm{P}$ as a donor atoms. The observed Pt-P1 and Pt-P2 length of 2.217(2) and 2.217(2) $\AA$. The $\mathrm{Pt}-\mathrm{Cl} 1$ and PtCl2 length of 2.3661(19) and $2.3661 \AA$ respectively of $\left[\mathrm{Pt}(\mathrm{k} 2-\mathrm{dppmCl}) \mathrm{Cl}_{2}\right]$ metal complex ${ }^{15}$. A summary of crystal data, experimental details, and refinement outcomes is shown in Table 1.

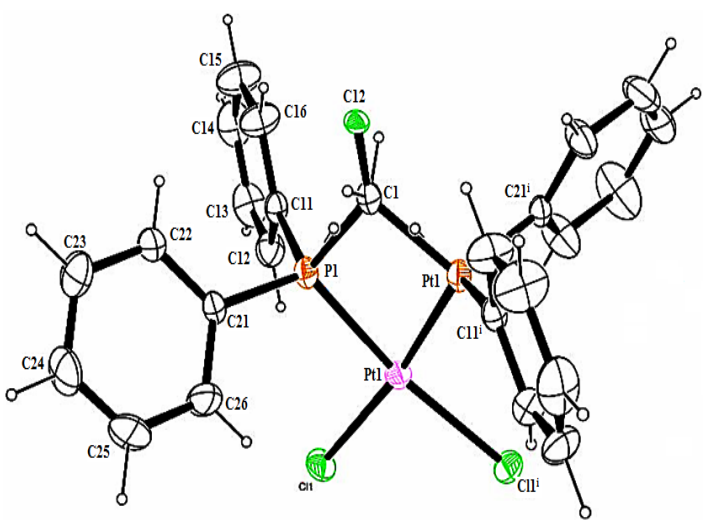

Fig. 1. Molecular structure of $\left[\mathrm{Pt}(\mathrm{dppmCl}) \mathrm{Cl}_{2}\right]$ complex

\section{X-ray Crystal structure}

Suitable crystals of the complex were produced by slow evaporation of a methylene chloride solution. A yellow crystal with approximate dimensions $0.04 \times 0.20 \times 0.21 \mathrm{~mm}^{3}$ was formed and the crystal was sent to $X$-ray analysis. The molecular 
structure is given in Fig. 1. Crystals of complex are monoclinic, space group $\mathrm{C} 2 / \mathrm{c}$ with $\mathrm{a}=16.2034(5)$, $b=7.8274(2), c=19.2496(6) A^{\circ}, \alpha=\gamma=90^{\circ}, \beta=98.918$ $\left(1^{\circ}, Z=4\right.$. The $R$ value is 0.03 (WR2=0.1178, $\mathrm{S}=1.30)$. The platinum center adopts a square planar geometry with Cl1-Pt1-P1 and Cl1-Pt1-P2 bonds angle of $98.10(7)^{\circ}$ and $98.10(7)^{\circ}$ respectively, the phosphine ligand is coordinated in bidentate fashion through two phosphorus atom, and the two chlorine atoms also coordinated to the metal center ${ }^{16,17,18}$. Table 2 gives the selected bond length and bond angles of metal complex.

\section{Infrared spectral}

The IR spectra of the metal complex are in agreement with $\mathrm{X}$-ray analysis data with respect to the condition of coordination. The infrared spectrum of bis(diphenylphos phino)methane ligand have bands at 3064, 2899, 1431 and $511 \mathrm{~cm}^{-1}$ are attributed to the stretching vibration of aromatic $v$ $(\mathrm{C}-\mathrm{H})$, aliphatic $v(\mathrm{C}-\mathrm{H}), v(\mathrm{P}-\mathrm{Ph})$ and aliphatic $v$ $(P-C)$ respectively ${ }^{19,20,21}$. The IR spectrum of complex also shows stretching vibrations assigned to the Pt-P bond at $280 \mathrm{~cm}^{-1}$ and Pt-Cl bond at $371 \mathrm{~cm}^{-1} 22,23$.
Table 1: Crystallographic and structure refinement data for $\left[\mathrm{Pt}(\mathrm{dppmCl}) \mathrm{Cl}_{2}\right]$ complex

\begin{tabular}{|c|c|}
\hline Compound & {$\left[\mathrm{Pt}(\mathrm{dppmCl}) \mathrm{Cl}_{2}\right]$} \\
\hline $\begin{array}{l}\text { Empirical formula } \\
\text { Formula weight }(\mathrm{g} / \mathrm{mol})\end{array}$ & $\begin{array}{c}\mathrm{C}_{24.27} \mathrm{H}_{21.46} \mathrm{Cl}_{2} \mathrm{P}_{2} \mathrm{Pt}(\mathrm{Cl})_{0.729}(\mathrm{H})_{0.54} \\
667.43\end{array}$ \\
\hline $\mathrm{R}$ & 0.03 \\
\hline Temperature (K) & 200 \\
\hline $\begin{array}{l}\text { Wave length }\left({ }^{\circ} \mathrm{A}\right) \text {, } \\
\text { Crystal system }\end{array}$ & 0.71073, Monoclinic \\
\hline space group & $\mathrm{C} 2 / \mathrm{c}$ \\
\hline $\mathrm{a}\left({ }^{\circ} \mathrm{A}\right)$ & $16.2034(5)$ \\
\hline $\mathrm{b}\left({ }^{\circ} \mathrm{A}\right)$ & $7.8274(2)$ \\
\hline$c\left(^{\circ}\right)$ & $19.2496(6)$ \\
\hline$\alpha\left(^{\circ}\right)$ & 90 \\
\hline$\beta\left(^{\circ}\right)$ & $98.918(1)$ \\
\hline$\gamma\left({ }^{\circ}\right)$ & 90 \\
\hline Volume $\left(A^{3}\right)$ & 2411.92(12) \\
\hline $\begin{array}{l}\text { Calculated density } \\
\left(\mathrm{mg} / \mathrm{m}^{3}\right)\end{array}$ & $4,1.838$ \\
\hline Z & 4 \\
\hline Crystal size & $0.04 \times 0.20 \times 0.21 \mathrm{~mm}$ \\
\hline $\begin{array}{l}\text { Theta range for } \\
\text { data collection }\end{array}$ & $2.9,28.4 \mathrm{deg}$ \\
\hline $\begin{array}{l}\text { Reflections } \\
\text { collected/unique }\end{array}$ & $16294,3007,[\mathrm{R}(\mathrm{int})=0.030]$ \\
\hline $\begin{array}{l}\text { Observed Data } \\
{[I>2.0 \text { sigma(I)] }}\end{array}$ & 2930 \\
\hline $\mathrm{R}, \mathrm{wR} 2, \mathrm{~S}$ & $R=0.0478 \quad w R 2=0.1178 \quad S=1.30$ \\
\hline $\begin{array}{l}\text { Min. and Max. } \\
\text { Resd. Dens }\end{array}$ & {$[-1.71,4.83] \mathrm{e} / \mathrm{Ang}^{\wedge} 3$} \\
\hline
\end{tabular}

Table 2: Selected Bond length [A] And Bond Angles [Degree] of [Pt(k2-dppmCl)CI2] Complex

\begin{tabular}{|c|c|c|c|c|c|}
\hline \multicolumn{2}{|c|}{ Bond distance } & \multicolumn{2}{|c|}{ Bond angle } & \multicolumn{2}{|c|}{ Bond angle } \\
\hline Pt1-Cl1 & $2.3661(19)$ & Cl1-Pt1-P2 & $98.10(7)$ & $\mathrm{C} 14-\mathrm{C} 13-\mathrm{H} 13$ & 120.00 \\
\hline Pt1-P2 & $2.217(2)$ & $\mathrm{Cl} 1-\mathrm{Pt1}-\mathrm{P} 1$ & $98.10(7)$ & $\mathrm{C} 13-\mathrm{C} 14-\mathrm{H} 14$ & 119.00 \\
\hline Pt1-P1 & $2.217(2)$ & Cl1-Pt1-Cl1_a & $90.02(6)$ & $\mathrm{C} 15-\mathrm{C} 14-\mathrm{H} 14$ & 119.00 \\
\hline Pt1-Cl1_a & 2.3661(19) & Cl1-Pt1-P2_a & $171.58(7)$ & $\mathrm{C} 14-\mathrm{C} 15-\mathrm{H} 15$ & 121.00 \\
\hline Pt1-P2_a & $2.217(2)$ & Cl1_a-Pt1-P2 & $171.58(7)$ & $\mathrm{C} 16-\mathrm{C} 15-\mathrm{H} 15$ & 121.00 \\
\hline $\mathrm{P} 1-\mathrm{C} 21$ & $1.816(7)$ & C14-C15-C16 & $118.6(9)$ & P2-C11-C16 & $122.9(6)$ \\
\hline P1-C1 & $1.85(3)$ & C11-C16-C15 & $121.1(9)$ & $\mathrm{C} 12-\mathrm{C} 11-\mathrm{C} 16$ & $119.7(7)$ \\
\hline P1-C11 & $1.808(8)$ & $\mathrm{P} 2-\mathrm{C} 21-\mathrm{C} 22$ & $121.9(6)$ & P1-C11-C12 & $117.5(6)$ \\
\hline P2-C11 & $1.808(8)$ & P2-C21-C26 & $117.9(6)$ & $\mathrm{P} 1-\mathrm{C} 11-\mathrm{C} 16$ & $122.9(6)$ \\
\hline P2-C21 & $1.816(7)$ & $\mathrm{P} 1-\mathrm{C} 21-\mathrm{C} 22$ & $121.9(6)$ & $\mathrm{P} 2-\mathrm{C} 11-\mathrm{C} 12$ & $117.5(6)$ \\
\hline $\mathrm{C} 21-\mathrm{C} 26$ & $1.362(12)$ & P2-Pt1-P2_a & $73.87(8)$ & $\mathrm{C} 11-\mathrm{C} 12-\mathrm{C} 13$ & $119.2(8)$ \\
\hline $\mathrm{C} 21-\mathrm{C} 22$ & $1.386(12)$ & Cl1_a-Pt1-P1 & $171.58(7)$ & $\mathrm{C} 11-\mathrm{C} 16-\mathrm{H} 16$ & 119.00 \\
\hline $\mathrm{C} 22-\mathrm{C} 23$ & $1.381(13)$ & Cl1_a-Pt1-P2_a & $98.10(7)$ & $\mathrm{C} 15-\mathrm{C} 16-\mathrm{H} 16$ & 119.00 \\
\hline $\mathrm{C} 23-\mathrm{C} 24$ & $1.387(14)$ & C1-P1-C11 & $107.4(5)$ & $\mathrm{C} 21-\mathrm{C} 22-\mathrm{H} 22$ & 120.00 \\
\hline $\mathrm{C} 24-\mathrm{C} 25$ & $1.358(17)$ & C1-P1-C21 & $108.0(5)$ & $\mathrm{C} 23-\mathrm{C} 22-\mathrm{H} 22$ & 120.00 \\
\hline C25-C26 & $1.390(13)$ & P1-C21-C26 & $117.9(6)$ & $\mathrm{C} 22-\mathrm{C} 23-\mathrm{H} 23$ & 120.00 \\
\hline $\mathrm{C} 12-\mathrm{H} 12$ & 0.9500 & $\mathrm{C} 22-\mathrm{C} 21-\mathrm{C} 26$ & $120.2(7)$ & $\mathrm{C} 24-\mathrm{C} 23-\mathrm{H} 23$ & 120.00 \\
\hline $\mathrm{C} 13-\mathrm{H} 13$ & 0.9500 & $\mathrm{C} 21-\mathrm{C} 22-\mathrm{C} 23$ & $120.2(8)$ & $\mathrm{C} 12-\mathrm{C} 13-\mathrm{C} 14$ & $119.8(9)$ \\
\hline $\mathrm{C} 14-\mathrm{H} 14$ & 0.9500 & C22-C23-C24 & 119.6(9) & $\mathrm{C} 13-\mathrm{C} 14-\mathrm{C} 15$ & $121.7(9)$ \\
\hline $\mathrm{C} 15-\mathrm{H} 15$ & 0.9500 & C23-C24-C25 & $119.5(9)$ & C24-C25-H25 & 119.00 \\
\hline $\mathrm{P} 2-\mathrm{H} 2$ & 1.0000 & Pt1-P1-C1 & $97.0(9)$ & $\mathrm{C} 26-\mathrm{C} 25-\mathrm{H} 25$ & 119.00 \\
\hline C11-C12 & $1.388(11)$ & Pt1-P1-C11 & $117.7(3)$ & $\mathrm{C} 23-\mathrm{C} 24-\mathrm{H} 24$ & 120.00 \\
\hline C11-C16 & $1.391(12)$ & Pt1-P1-C21 & $117.2(3)$ & $\mathrm{C} 25-\mathrm{C} 24-\mathrm{H} 24$ & 120.00 \\
\hline C12-C13 & $1.394(12)$ & $\mathrm{C} 11-\mathrm{P} 1-\mathrm{C} 21$ & $108.1(3)$ & $\mathrm{C} 21-\mathrm{C} 26-\mathrm{H} 26$ & 120.00 \\
\hline C13-C14 & $1.364(16)$ & C11-P2-C21 & $108.1(3)$ & $\mathrm{C} 25-\mathrm{C} 26-\mathrm{H} 26$ & 120.00 \\
\hline C14-C15 & $1.384(15)$ & C24-C25-C26 & $121.4(10)$ & & \\
\hline C15-C16 & $1.369(14)$ & C21-C26-C25 & $119.2(9)$ & & \\
\hline $\mathrm{C} 16-\mathrm{H} 16$ & 0.9500 & $\mathrm{C} 11-\mathrm{C} 12-\mathrm{H} 12$ & 120.00 & & \\
\hline
\end{tabular}




\section{CONCLUSION}

In conclusion, new $\mathrm{Pt}(\mathrm{II})$ metal complex of tertiarydiphosphine (dppm) can be readily obtained by the reaction of 1,1-Bis(diphenylphosphino)methane with $\mathrm{Pt}(\mathrm{II})$ chloride as given in the Fig. 1. The central platinum atom is bonded by two chlorine and two phosphorus atoms of 1,1-Bis(diphenylphosphino) methane ligand, thus forming the $\left[\mathrm{Pt}\left(\mathrm{k}^{2}-\mathrm{dppmCl}\right) \mathrm{Cl}_{2}\right]$ square planar compound. The chlorine atom bonded to methylene group of dppm ligand that make the complex new.

\section{ACKNOWLEDGEMENT}

The authors wish to thank the chemistry Department. College of Education-Salahaddin University for their helping to finish our present study and the authors also thank the department of Physics, college of science, at Halabja University for their helps.

\section{Conflicts of Interest}

The authors declare no conflict of interest.

\section{REFERENCES}

1. Cornelis, T.; Chirs, J.; Koop, L. Coord. Chem. Rev., 2007, 356, 115-126.

2. Lagasse, F.; kagan, H. Chem. Pharm. Bull., 2000, 48, 315-324.

3. Özkar, S.; Kayran, C.; Tekkaya, A. Turk. J. Chem., 1996, 20, 74-79.

4. Kamer, P.C.; Van Leeuwen, P.W.; Reek, J.N. Acc. Chem. Res., 2001, 34, 895-904.

5. Ali, K.O.; Mohammad, H.A.; Gerber, T.; Hosten, E. Orient. J. Chem., 2017, 33, 584-592.

6. Pourshahbaz, M.; Irandoust, M.; Rafiee, E.; Joshaghani, M. Polyhedron., 2009, 28, 609-613.

7. Courtney, D.; Samuel, P.; Chelsie, M.; Anastasia, V.; Brian, J.; Jason, M.; Scott, R. Inorg. Chem., 2015, 54, 5646-5659.

8. Johanna, G.; Gerard, V.; Keeb, V.; David, M. J. Organomet. Chem., 1983, 256, 375-389.

9. Mariusz, P.; Artur, M. Inorg. Chem., 2010, 49, 578-582.

10. Lennart, T.; Viktoria, H. Inorg. Chem., 2017, 56, 8599-8607.

11. Daura-Oller, E.; Poblet, J.; Bo, C. Dalton Trans., 2003, 1, 92-98.

12. Deredas, D.; Maniukiewicz, W.; Wojciechowski, J.; Wolf, W.; Paluch, P.; Janecki, T.; Rózalski, M.; Krajewska, U.; Janecka, A.; Krawczyk, H.
RSC Advances., 2013, 3, 6821-6832.

13. Altomare, A.; Burla, M.; Camalli, M.; Cascarano, G.; Gia, C.; Guagliardi, A.; Moliterni, A.; Polidori, G.; Spagna, R. J. Appl. Crystallogr., 1999, 32, 115-119.

14. George, M. Sheldrick. Acta Cryst., 2015, C71, 3-8.

15. Takayoshi, S.; Hiroshi, Y.; Masayuki, F.; Akira, H.; Hideo, D. Acta Cryst. E., 2015, E71, 447-451.

16. AL-Jibori, S.; L-Nassiry, A.; Hogarth, G.; Salassa, L. Inorganic Chim. Acta., 2013, 398, 46-53.

17. Al-Jibori, S.; Al-Jibori, Q.; Schmidt, H.; Merzweiler, K.; Wagner, C. Inorganic Chim. Acta., 2013, 402, 69-74.

18. Steffen, W.; Palenik, G. Inorg. Chem., 1976, 15, 2432-2439.

19. Horn, H.; Sommer, k. Spectrochim Acta A Mol. Spectrosc., 1971, A27, 1049-1054.

20. Thomas, L.; Chittenden, R. Spectrochim Acta A Mol. Spectrosc., 1965, A21, 1905-1914.

21. Witschard, G.; Griffin, C. Spectrochim Acta A Mol. Spectrosc., 1963, A 19, 1905-1910.

22. Jason, A.; Trystan, B.; David, A.; Baira, D.; Daniil, O.; Rohul, A.; Gregory, M. RSC Advances., 2013, 3, 22140-22149.

23. Algül, Ö.; Özçelik, B.; Abbasoglu, U.; Gümüs, F. Turk J Chem., 2005, 29, 607-615. 